\title{
2015年（第31回）Japan Prize「資源、エネルギー、社会基盤」分野
}

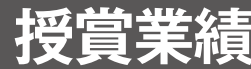

\section{流域管理の革新的概念の \\ 創出と水災害軽減への貢献}

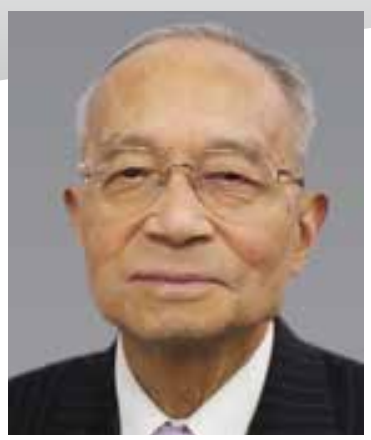

高橋 裕 博士

東京大学名誉教授

\section{概 要}

私たち人間は、河川の恩恵を受けて生活して いますが、ときに河川は増水による堤防決壊な ど甚大な水倓害をもたらします。高橋裕博士は、 戦後に生じた台風による洪水被害など、水災害 についての現地調查とデータ解析を行い、明治 以来の大規模な河川改修や開発による流域の変 貌が、洪水規模の拡大につながったことを科学 的に実証。そして、水災害の規模を小さくする ためには、堤防などの河川改修だけでなく、調 節池などによる流域管理や健全な水循環の維持 が重要であるといった「総合治水対策」の考え 方を提案し続けてきました。博士の提案は、河 川や水全般に関わる様々な法律として結実しま した。また、温暖化によって世界中で多発して いる水災害の対策にも生かされています。

\section{明治維新以降の河川改修と 流域の変貌が大洪水の背景に}

高橋博士は、1927年に静岡県に生まれ、安倍 川の伏流水がこんこんと湧く田園地帯で育ちま した。終戦から 2 年後の1947年に東京大学第二
工学部土木工学科に入学。志望動機について 高橋博士は「当時、戦争で国土が荒廃していた ばかりか、毎年、大きな水害にも見舞われた。 災害から復興することが国づくりの第一歩であ ると考えた」と話しています。

実際、戦後の15年間は、日本の歴史のなかで も甚大な台風などの水焱害が相次いだ時代でし た。博士が東京大学に入学した年に起きたカス リーン台風では、利根川の堤防が決壊し首都東 京の東部を水没させる事態となり、1959年の伊 勢湾台風は4,697名の死者をもたらしました。

博士は、カスリーン台風以後起こった水災害 の現地調査を行いましたが、大学院進学後の 1953年に行った筑後川での調查は、明治維新以 降の開発による国土の歴史的変遷と水災害との 関連を読み解く画期的な成果をもたらしまし た。

このとき博士は、地元の古老たちが「この ごろは洪水の出足が早い」「若いころに比べて、 上流に降った雨が下流に出るのが大変早くなっ た」と話しているのに注目しました。

それはなぜか。明治政府は、積極的に西洋の 科学技術を輸入し、河川技術に関しては1872年 にオランダの技術者を招き、河川改修事業の近 
代化に踏み切りました。このとき明治政府は、 長年、水贸害に悩まされてきた人々を守るため に、大きな河川には連続堤防を作り、たとえ大 洪水が起きても水を堤防外に一滴も出さないと いう方向性を打ち出したのです。

こうした取り組みによって大正から昭和にか けて中小の洪水は食い止めることができました が、同時に、洪水のたびに流量が増加するとい う現象が起きていました。堤防ができる前は、 上流で小さな汇濫が起き、水が主要河川に集中 するのを遅らせていましたが、連続堤防により 大量の雨が短時間で下流の都市部に到達するよ うになったのです。

博士は、地域に残っている古い文献資料、気 象および河川のデータなどを丁寧に調べ上げ、 明治以来の堤防による河川改修や開発に伴う河 川流域の変貌が洪水規模の増加をもたらしてい ることを科学的に解明。1955年に論文「Gradual Alteration in the Flow Characteristics of the Chikugo-River Flood（筑後川で起きた洪水の特

徵の段階的変化)」を著しました。

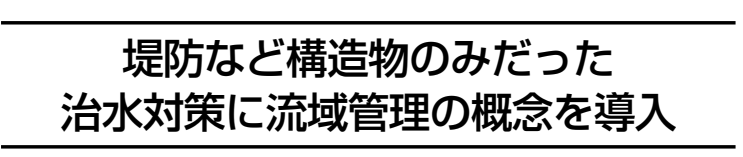

1958年に起きた狩野川台風は、高橋博士が都 市化が水災害にもたらす影響について考える きっかけになりました。狩野川台風は、静岡県 に大きな災害をもたらした後、神奈川県の江ノ 島付近で再上陸したのです。人口が増え始めて いた東京や横浜では、山林や田畑の減少により 土地の保水力が低下すると同時に、河川周辺の 平地には新興住宅地や工場の造成が進んでいま した。こうした場所で大規模な洪水被害が起き たのです。同様の水災害は60年代にも相次ぎ、 高橋博士はこうした状況を「新型都市水害」と 名付けました。

1961年に東京大学工学部助教授、68年に同教 授となった博士が指導する学生たちを叱咤激励 するときに発したのは「よく川を見ろ」という 言葉でした。河川の観察はもちろん、流域の地 形や植生を分析し、さら

\section{戦後の水災害被害額の推移}

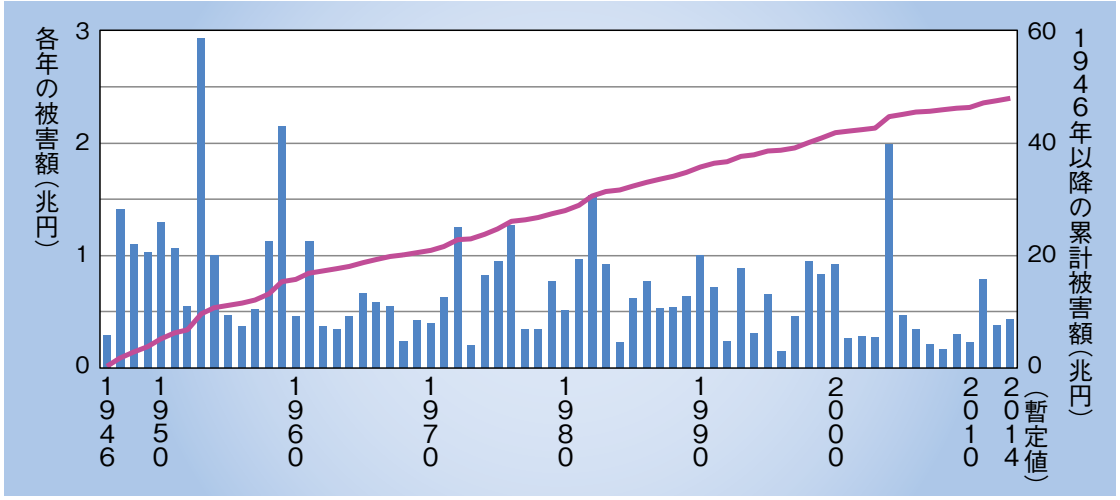

にはそこに暮らす人々の 生活を見る。博士の研究 は、特定の学問領域にと らわれない「学際研究」 の原点といってもいいか もしれません。

博士は、このような豊 富な現地調查から得た新 たな視点を1971年の著書 
総合治水対策の概要

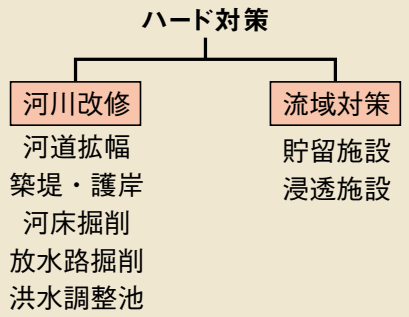

高橋博士の河川哲学を具現化した現在の「総合治水対策」の例。明治維新以降進められた河川 改修だけでなく、流域の水源保全、健全な水循環の保持などソフト対策によって水災害のリス クの低減を図るとともに、災害時に人命を守ることを目指している。

\section{鶴見川の総合治水対策の例}

\section{平常時の多目的遊水地}

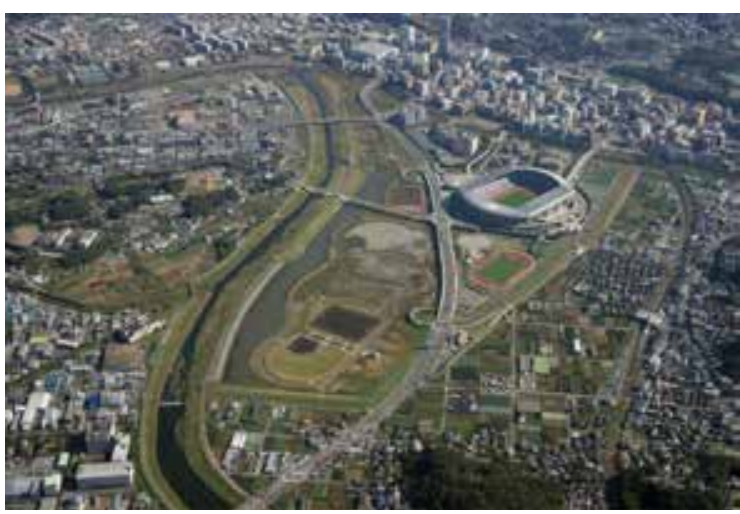

\section{洪水調整時}

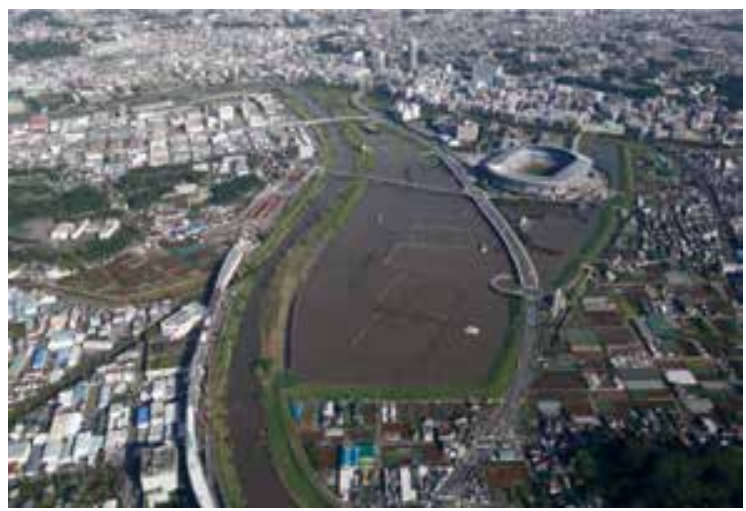

1958 年の狩野川台風で甚大な浸水被害をもたらした鶴見川で は、大規模な多目的遊水地が作られている。川の水量が増したと きには遊水地に水を引き入れ住宅地などの浸水を防ぐ。 (国土交通省)
『国土の変貌と水害』で 発表。そこには堤防など の構造物のみによる治水 から、流域とのかかわり において治水政策を進め るべきだという提案が盛 り込まれていました。

この新たな概念は、国 の治水事業を大きく変え ることにもつながりまし た。1980年からは雨水が大きな河川に流れこむ 流域に遊水池、調節池などを設置することで、 洪水流出を抑える「総合治水」による対策が行 われるようになりました。特に戦後の開発によ り水焱害が激化した都市地域を流れる主要河川 を皮切りに全国へと展開され、水災害軽減に多 大な効果をもたらしました。

\section{モンスーン地帯の水災害対策に尽力 新たな河川哲学が世界を変える}

戦後ずっと日本の川を見つめてきた高橋博 士。博士が1990年に大学の教科書として執筆し た『河川工学』では、従来の河川工学には見ら れない新たな河川哲学が随所に盛り込まれまし た。もっとも重要なことは、従来は河道（水 が流れる道筋）への治水・利水の施設に重点が 置かれていたものを、より広く、流域を視野に 置いたことです。また、河川事業が環境へ与え る影響を考慮することや、河川計画への住民参 加の配慮などが提言されています。河川、自然 
環境、住民の生活空間を一体化して考える、新 たな河川工学の体系を創造したといっていいで しょう。

博士の新しい治水概念は、1997年の河川法改 正の礎となり、これは今も世界で最も進んだ河 川法の一つになっています。さらに博士は、こ れまで河川、地下水、農業用水などがそれぞれ の行政分野で独自に管理されていたものを、流 域の水資源として一元的に有効管理することが 重要と主張し、その理念は2014年の各党合意の 議員立法により「水循環基本法」として結実し ました。

海外においては、博士は、自然や社会が日本 と似通っているアジアモンスーン地域に属する 13力国の協力体制を構築し、この分野に関する 地域協力や人材育成にも尽くしました。その結 果、こうした地域の水災害の軽減や河川環境の 改善が実現しました。特に、1991年にバングラ デシュで約14万人の犠牲者を出したサイクロン 災害後には、国連報告書で「堤防整備よりも避 難のための情報提供やシェルターの整備を充実 すべき」という提言が取りまとめられました。 提言に基づく日本のODA援助による整備も進 み、2007年に発生した同規模の高潮災害におけ る犠牲者は約 4,000 人にとどまりました。

こうした博士の活動に対して、水資源分野で 国際的にもっとも権威ある専門誌『International Journal of Water Resources Development』は、 創刊25周年の 2009 年に初めて個人を取り上げた 特集を組み、博士の水資源・治水分野での多大
な貢献を称えました。

近年、世界中で温暖化が影響していると考え られる大規模な水災害が多発しており、新たな 治水対策・水資源管理が求められています。高 橋博士が提案してきた河川哲学は、次世代の治 水対策の基礎として生き続けることでしょう。 